\title{
Dociekania
}

\section{Antropologia taktylna. Uwagi wstępne}

Maciej Topolski

TEKSTY DRUGIE 2021, NR 1, S. 360-374

DOI: $10.18318 /$ td.2021.1.22 | ORCID: 0000-0002-3107-9394

\section{"Antropologia taktylna nie istnieje"}

Takim stwierdzeniem posłużyli się w jednym ze swoich tekstów odpowiedzialni za rewolucję zmysłową badacze z Centre for Sensory Studies w Montrealu, Constance Classen i David Howes'. Co mówi nam ta konstatacja? Weźmy na początek słowo „taktylny”. Pochodzi ono od łacińskiego tactus, które oznacza nie tylko zmysł dotyku, lecz także czynności z tym zmysłem związane, a przywoływane przez znaczenie pokrewnego czasownika tangere: czuć, oddziaływać, nieść, dotrzeć, graniczyć, przylegać, uderzać, poruszać, trzymać, ukłuć, wziąć, odnosić się².

1 C. Classen, D. Howes The Museum as Sensescape: Western Sensibilities and Indigenous Artifacts, w: Sensible Objects: Colonialism, Museums and Material Culture, ed. by E. Edwards, Ch. Gosden, R.B. Phillips, Berg Publishers, Oxford-New York 2006, s. 212. Jeżeli nie podano inaczej, wszystkie przytoczenia podaję w moim przekładzie.

2 A New Latin Dictionary, ed. by E.A. Andrews, revised, enlarged, and in great part rewritten by C.T. Lewis, C. Short, Harper \& Brothers Publishers, New York-Oxford 1891, s. 1833, 1840. To z powodu wieloznaczności tego słowa nie decyduję się na określenie "haptyczny", które

\author{
Maciej Topolski, \\ mgr - doktorant \\ i wykładowca na \\ Wydziale Polonistyki \\ Uniwersytetu Jagiel- \\ lońskiego. Laureat \\ Mitacs Globalink Re- \\ search Award (2019). \\ Ostatnie publikacje: \\ tomy wierszy na \\ koniec ida (Łódź 2017, \\ nominowany do \\ Nagrody Literackiej \\ Gdynia 2018) oraz \\ LUXUS (Łódź 2019). \\ Zainteresowania \\ badawcze: antro- \\ pologia zmysłów, \\ taktylność, studia nad \\ cielesnością.
}


Wszystkie te znaczenia wskazują zarówno na działania wykonywane przez dłoń, która uznawana jest najczęściej i błędnie za główny narząd dotyku, jak i na ruch całego ciała, stany emocjonalne, mowę czy relacje przestrzenne ${ }^{3}$. Tak wiele znaczeń przypisywanych zmysłowi dotyku okazuje się problematyczne, co każe zapytać, czym tak naprawdę jest dotyk. „[C]zy dotyk jest istotnie grupą zmysłów, czy jednym? Dalej, co jest organem zmysłu dotyku? Czy jest nim ciało - a w innych jestestwach odpowiednik ciała - czy też nie?"4. Odpowiedź na te pytania, które sformułował dwa tysiące lat temu Arystoteles, pozwoli lepiej zrozumieć przyczyny nieistnienia antropologii taktylnej.

Dotyk uznawany jest za "matkę zmysłów” lub „zmysł zmysłów”. Jest to zmysł pierwszy pod względem chronologicznym, wykształca się bowiem już w pierwszych tygodniach po zapłodnieniu komórki jajowej, kiedy skóra jest zdolna odbierać bodźce. Jest to również zmysł najbardziej niezbędny do życia; człowiek pozbawiony wzroku, słuchu, powonienia czy smaku potrafi funkcjonować w świecie, nie może jednak przeżyć, kiedy odarty jest z organu zmysłu dotyku, czyli skóry. Skóra oblekająca ciało człowieka stanowi jego największy organ zawierający ogromną liczbę receptorów dotykowych ${ }^{5}$. W istocie człowiek, nie będąc dotykany, to jest nie wchodząc w nieustanne interakcje z otoczeniem, nie może przeżyć 6 . W przeciwieństwie

odwołuje etymologicznie do "bycia w kontakcie” lub "bycia zdolnym do wejścia w kontakt (poprzez dotyk)". W studiach kulturowych haptyczność jest równoznaczna z taktylnością, często jednak ukazywana jest jako jedna z możliwości widzenia (po omacku, z bliska, jak twierdzi Gilles Deleuze - por. Y. Ohta What is the haptic? Consideration of Logique de le Sensation and Deleuze's theory of sensation, "Aesthetics” 2003 no. 17, s. 13-24).

3 Słowa "dotykowy" i "taktylny" nie są synonimami, jak chciałaby Anna Łebkowska w tekście Afirmacja dotyku w dyskursie współczesności, w: W kulturze dotyku? Dotyk i jego reprezentacje w tekstach kultury, red. A. Łebkowska, Ł. Wróblewski, P. Badysiak, Nomos, Kraków 2016, s. 13. "Dotyk" pochodzi od słowa "tknąć", które ma o wiele węższy zakres znaczeń: „zbliżyć się, trącić", „uderzyć ręką, bronią", "opanować, ogarnąć (o odczuciach)”, " dotknąć kogoś (o chorobie)”, "poruszyć uczuciowo”, „pozwać do sądu”, „powołać się na kogoś”, "dotyczyć czegoś”. Obu tych słów - taktylny i dotykowy - używam wymiennie, z uwzględnieniem wielości i odmienności ich znaczeń.

4 Arystoteles O duszy, w: tegoż, Dzieła wszystkie, t. 3, tłum., wstępy i komentarze P. Siwek, PIW, Warszawa 2003, s. 103 (część 11, zatytułowana "Dotyk i jego przedmiot").

5 Por. M. Grunwald Homo Hapticus. Dlaczego nie możemy żyć bez zmysłu dotyku?, przeł. E. Kowynia, Wydawnictwo Uniwersytetu Jagiellońskiego, Kraków 2019, s. 73-74.

6 Sytuacja, gdy ludzkie ciało nie wchodzi w żadne interakcje, jest niewyobrażalna i niemożliwa. Jak stwierdzi Ashley Montagu, "dotyk jest podstawową potrzebą behaworialną, 
do pozostałych zmysłów - wzroku, słuchu, węchu, smaku - dotyk nie ma swojego „miejsca”. Wszystkie zmysły znajdują się w konkretnym narządzie, tam, gdzie odbywa się stymulacja. Ten wzorzec decyduje o rozmieszczeniu receptorów w organizmie, nie dotyczy on jednak dotyku, którego receptory znajdują się na całej przestrzeni ciała z wyjątkiem mózgu, tkanki chrzęstnej i rogówki oraz większości organów wewnętrznych (dla przykładu nerek, płuc i śledziony). Za podstawę zmysłu dotyku, a zatem za odpowiadające za rozwój biologiczny, kształtowanie świadomości własnego ciała i własnego „ja”, uznawane są również zjawiska propriocepcji (rejestrowanie zmian położenia ciała) ${ }^{7}$ i interocepcji (rejestrowanie stanu całego organizmu) ${ }^{8}$.

Fakty biologiczne nie tłumaczą bezpośrednio powodów, dla których antropologia taktylna nie wytworzyła się jako oddzielna dziedzina badań, nie przekładają się też na znaczenia, jakie są przypisywane zmysłowi dotyku w konkretnej kulturze (w tym wypadku zachodniej). Umożliwiają jednak sformułowanie potencjalnych nowych lub zapomnianych sposobów rozumienia tego zmysłu, a tym samym wskazują na krytyczny jego - ściślej badań dotyczących tego zmysłu - potencjał względem nie tylko dominującej kultury, lecz także struktur społeczno-kulturowych (w tym struktur akademickich). Rozumienie dotyku jako zmysłu pierwszego, jak również zmysłu czucia i bliskości, sprzeciwia się aktualnej od czasów antycznych hierarchii zmysłów, według której zmysły wzroku i słuchu uznawane są za zmysły wyższe, a co za tym idzie, dostarczające najwięcej informacji i odpowiadające „wysokiemu” myśleniu abstrakcyjnemu, natomiast zmysły węchu, smaku i dotyku traktowane jako zmysły poślednie, niskie, cielesne, a nawet zwierzęce. Co więcej, sugeruje, że zmysł dotyku dotyczy zarówno człowieka, jak i innych osób nieludzkich oraz uniemożliwia wytworzenie dystansu,

tak samo jak oddech jest podstawową potrzebą fizyczną". Zob. A. Montagu Touching: the human significance of the skin, HarperCollins Publishers, New York 1986, s. 46.

7 J. Cole British pioneers of research into human haptic perception, w: Human Haptic perception: basics and applications, ed. by M. Grunwald, Birkhäuser, Basel-Boston-Berlin 2008, s. 41-53.

8 A.D. Craig How do you feel? Interoception: the sense of the physiological condition of the body, "Nature Reviews Neuroscience" 2002 vol. 3, s. 655-666.

9 Jolanta Brach-Czaina w eseju pełnym trafnych intuicji, zatytułowanym Dotknięcie świata, zapisuje: „naszą mocną stroną może być przecież posiadanie właściwości wspólnych, łączących z nieprzeliczonym bogactwem bytów zdolnych dotykać świata". Por. J. Brach-Czaina Dotknięcie świata, w: tejże, Błony umysłu, Sic!, Warszawa 2003, s. 61. Z kolei Donna J. Haraway otwiera książkę When Spieces Meet pytaniami dotyczącymi podobnych kwestii: „Kogo i czego dotykam, kiedy dotykam swojego psa? W jaki sposób «stawanie się wspólnym» jest praktyką stawania 
również intelektualnego, względem percypującego ciała (dotykający zawsze jest w bliskości ze sobą i ze światem). Wyszczególnione w drastycznym skrócie funkcje, jakie pełni zmysł dotyku, a także znaczenia, jakie są mu przypisane, wskazują przede wszystkim na potrzebę rezygnacji ze ścisłego i funkcjonalnego podziału ludzkiego sensorium na pięć zmysłów, a tym samym rozszerzenia ludzkiej percepcji - nie tylko przez rozwój technologiczny czy działanie substancji psychoaktywnych ${ }^{10}$. Warto przywołać w tym kontekście słowa C. Nadii Serematakis:

Zmysły zostały od siebie oddzielone, przedefiniowane i potraktowane jako funkcjonalne narzędzia oraz środki i przedmioty utowarowienia. Wycinanie i oddzielanie od siebie poszczególnych obszarów percepcji uzasadnia również całkowitą dosłowność zmysłowego doświadczenia. Dosłowność stanowi symboliczną logikę stworzoną przez naukową racjonalizację zmysłów, a także kulturę wyspecjalizowanej konsumpcji. [...] Dosłowność rzeczy jako jej najbardziej przyswajalny i sprzedawalny wymiar stanowi podstawę hiperkonsumpcji. Będąc kodem kultury, dosłowność narzuca i wyznacza normy ograniczonych, funkcjonalnych i powtarzalnych relacji z jednorazowymi wytworami. ${ }^{11}$

W obręb zmysłu dotyku włączane są nie tylko zjawiska propriocepcji i interocepcji, lecz także chronocepcji (odczuwania upływającego czasu), kinestezji (zmysłu ruchu), termocepcji (rozpoznawania zmian temperatury na skórze) czy equilibrocepcji (poczucia równowagi) ${ }^{12}$. Z pewnością możliwe jest wyszczególnienie kolejnych zjawisk odpowiadających zniuansowanemu doświadczeniu taktylnemu, co więcej, połączenie zmysłu dotyku z innymi zmysłami, między innymi w sposób zaproponowany przez Michela Serres'a, który twierdzi, że skóra obejmuje, implikuje i zawiera wszystkie pozostałe narządy zmysłów, a czyniąc w ten sposób, tworzy model, w jaki

się światowym?" Por. D.J. Haraway When Spieces Meet, University Of Minnesota Press, Minneapolis 2008, s. 3 .

10 Por. A. Huxley Drzwi percepcji; Niebo i piekło, przeł. M. Mikita, Wydawnictwo Cień Kształtu, Warszawa 2012.

11 C.N. Serematakis Pamięć zmysłów. Oznaki przejściowości, przeł. K. Kuberska, K. Pietrowiak, „Etnografia. Praktyki, Teorie, Doświadczenia" $2018 \mathrm{nr}$ 4, S. 142.

12 P. Vannini, D. Waskul, S. Gottschalk The Senses in self, society, and culture: a sociology of the senses, Routledge, New York-London 2002, s. 3-22. 
zmysły wzajemnie siebie obejmują ${ }^{13}$. Wszystko to sprawia, że dotyk nie daje się uchwycić, przypomina, jak trafnie ujął to Pablo Maurette, wielogłową hydrę lub kostkę mydła pod wodą ${ }^{14}$.

Zadaniem antropologii taktylnej jest nie tyle „schwytanie” doświadczenia taktylnego, ile próba oddania jego specyfiki i kompleksowości, wykraczającej daleko poza racjonalny podział. Tym samym ta nieistniejąca dziedzina badań powinna uwzględnić te różnice między znaczeniami przypisywanymi zmysłowi dotyku, które dotyczą zarówno odmiennych kultur, jak i epok historycznych, przede wszystkim jednak pojedynczych ciał, z jednej strony w kontekście zróżnicowanych wrażeń odbieranych przez konkretne części ciała (usta, stopy, język, dłonie, plecy, piersi), z drugiej zaś zmian zmysłowości w zależności od wieku (ślady starzenia objawiające się zmarszczkami, plamieniami, zmianami pigmentacyjnymi na skórze, poznawcza rola ust u dzieci), płci (kobiet w relacji z nienarodzonym dzieckiem czy tych spośród osób transpłciowych, które doświadczają bycia „nie w swoim ciele”), rasy (jak w przypadku osób czarnych mających niby to twardszą i grubszą skórę) ${ }^{15} \mathrm{czy}$ niepełnosprawności (jak u osób pozbawionych dłoni) ${ }^{16}$. Różnice te ukażą, że stworzenie globalnej, uniwersalnej teorii dotyczącej doświadczenia taktylnego jest po prostu pozbawione sensu.

Antropologia taktylna powinna również uwzględnić różnorodne odczucia cielesne związane z doświadczeniem taktylnym (od rozkoszy przez poczucie wygody do bólu), wytworzyć pojęcia taktylne (jak „ego skóry” opisane szczegółowo przez Didiera Anzieu czy zmysłowe symulakrum u wspomnianego już Michela Serres'a) ${ }^{17}$, podjąć krytyczny namysł nad działalnością artystów

13 S. Connor Michel Serres' five senses, w: Empire of the senses: the sensual culture reader, ed. by D. Howes, Berg Publishers, Oxford-New York 2005, s. 323.

14 P. Maurette The forgotten sense. Meditations on touch, University of Chicago Press, ChicagoLondon 2018 s. ix-x.

15 Zob. M.M. Smith How race is made: slavery, segregation and the senses, University of North Carolina Press, Chapell Hill 2006, s. 16.

16 Zob. R. Garland-Thomson Hands, w: tejże, Staring: how we look, Oxford University Press, New York 2009, s. 119-139.

17 Zob. M. Lafrance From the skin ego to the psychic envelope: an introduction to the work of Didier Anzieu, w: Skin, culture and psychoanalysis, ed. by S.L. Cavanagh, A. Failler, Palgrave Macmillan, Basingstoke 2013, S. 16-44; M. Serres The five senses: a philosophy of mingled bodies (I), transl. by M. Sankey, P. Cowley, Continuum, London 2008, s. 208-209. Symulakrum nie jako obraz-symulacja, która pozoruje rzeczywistość lub tworzy własną jej wersję, lecz odbitki przedmiotów, delikatne obrazy przenikające zmysły i umożliwiające ich poznanie. 
wychodzących poza wizualność (jak Kate McIntosh w performansie In many hands czy Rafał Pierzyński w projekcie Touching (Is Electric)), wytworzyć nowe rozumienie odbiorcy/współuczestnika (nie widza i słuchacza, lecz dotykającego) ${ }^{18}$ czy wziąć pod uwagę perspektywę klasową (np. w kontekście pism Karola Marksa, według którego oczekiwana rewolucja przyniesie ze sobą wyniesienie ze zmysłów niskich) ${ }^{19}$.Ta dziedzina badań nie powinna uznawać „nieprzetłumaczalności” doświadczeń taktylnych - podobnie jak pozostałych wrażeń pochodzących ze zmysłów bliskości, czyli zapachu i smaku - jednocześnie godzić się na niemożność ich opisania czy skategoryzowania poza wizualnymi formami namysłu (tekst, obraz, film) ${ }^{20}$. Konsekwencją takiego stanowiska powinno być uznanie, że ten rodzaj antropologii można uprawiać tekstami innymi niż akademickie, jak również w medium innym niż tekst (niech za przykład posłuży dotykowa instalacja Haptic Field v 2.0 - Immersion Version, przygotowana przez Chrisa Saltera oraz TeZ) ${ }^{21}$. Celem tej dziedziny jest wytworzenie przestrzeni refleksji nad zmysłem dotyku, co oznacza między innymi wytworzenie konkretnej terminologii, która ją antropologicznie usensowni i będzie mogła służyć komunikacji² ${ }^{22}$ Ostatecznie badacze zajmujący się doświadczeniem taktylnym powinni dążyć do nowych sposobów rozumienia i prezentacji wiedzy, która utraci swój zobiektywizowany, zdesensualizowany i zdystansowany wymiar. Constance Classen ujmuje to następująco:

dotyk nie jest tak odległy od myśli, jak sobie to wyobrażamy. Ci, dla których jest najdalszy, to naukowcy. Chociaż wielu doktorantów pracujących nad swoją rozprawą dobrze wie, że myślenie przypomina szlifowanie, żucie i ważenie, to jednak akademicy z założenia patrzą na przedmiot swoich badań z obiektywnej odległości. Zamiast ujmować problem, naukowcy

Por. R. Blake Ethnographies of touch and touching ethnographies: some prospects for touch in anthropological enquiries, https://www.anthropologymatters.com/index.php/anth_matters/ article/view/224/378 (10.04.2020).

D. Howes Marx's skin, https://www.david-howes.com/senses/marxsskin.html (10.04.2020).

Por. S. Pink The future of visual anthropology: engaging the senses, Routledge, London-New York 2006.

Zorganizowana w Martin Gropius Bau w Berlinie w lipcu 2017, dostęp pod adresem: http:// www.chrissalter.com/haptic-field-v-2-0-immersion-version/ (10.04.2020). gan Press, Ann Arbor 2003, s. 58. 
rzucają na niego światło. Zamiast zajmować stanowisko, mają punkt widzenia. Wykorzystanie takich metafor wizualnych w pogoni za wiedzą zniechęca do aktywnego zaangażowania w przedmiot badań i promuje naukowy tryb obojętności ${ }^{23}$.

\section{Sensowność zmysłów}

Język angielski na określenie zmysłu i znaczenia ma to samo słowo, sense. We współczesnym języku polskim ta analogia jest w mniejszym stopniu uchwytna, lecz wciąż obecna w przymiotnikach sensoryczny i sensowny. Warto również przypomnieć, że w języku staropolskim „rozum” oznaczał - poza zdolnością myślenia, rozumienia i znaczenia czegoś - właśnie „zmysł fizyczny, czucie, sensus" ${ }^{24}$. Nie jest to przypadkowa zbieżność. Coś jest sensowne, a więc zgodne z myśleniem lub rozsądkiem, gdy jest sensoryczne, sensualne, czyli pozwala się ulokować w obrębie percepcji, odpowiada odbieranym wrażeniom zmysłowym. Friedrich Nietzsche w następujący sposób opisał zmysły w Jutrzence:

Oko me, bez względu na swą siłę lub słabość, widzi jeno na pewną odległość; w okręgu tym przebywam i żyję, ta linia widnokrężna jest mem najbliższem wielkiem i małem przeznaczeniem, którego uniknąć nie sposób. Każdą istotę otacza taki krąg współśrodkowy, posiadający właściwy sobie środek. Podobnie w ciasnej przestrzeni zamyka nas ucho, tak samo dotyk. Miarą tych widnokręgów, w które, ni to w więzienne cele, zamykają każdego z nas zmysły, mierzym tedy świat $[\ldots] .^{25}$

Porównanie zmysłów do kręgu i więziennej celi pozwala z jednej strony uznać je za przestrzenie ograniczone czy wręcz ograniczające zdolności poznawcze (intelektualne) człowieka, z drugiej zaś jako przeznaczone mu pole, za sprawą którego potrafi poznawać świat. Metaforyka użyta przez Nietzschego jest paradoksalna. Krąg zamykający odczuwanie zmysłowe może być w założeniu poszerzany, na przykład za sprawą technologii, jak pisze Nietzsche,

23 C. Classen Fingerprints. Writing about touch, w: Book of touch, ed. by C. Classen, Berg, OxfordNew York 2005, s. 5.

24 Hasło Rozum, w: Słownik staropolski, red. S. Urbańczyk, J. Kuraszkiewicz i in., IJP PAN, Kraków 1977-1981, t. 8, s. 21.

25 F. Nietzsche Jutrzenka. Myśli o przesq̨dach moralnych, przeł. S. Wyrzykowski, Vis-à-vis Etiuda, Kraków 2017, s. 99 (rozdział "W więzieniu”). 
„narząd[ów], które całe systemy słoneczne pomniejszałyby i zdrabniały dla naszego odczuwania do rozmiarów jednej jedynej komórki”26. Głównie jednak określa konkretny zakres zmysłowości - wszystko, co wykracza poza niego, nie jest odczuwane (sensualne), jest więc pozbawione sensu (nonsensowne $)^{27}$. Po przeniesieniu powyższej interpretacji fragmentu Jutrzenki Nietzschego na pole badań naukowych można stwierdzić, że zmysł dotyku pozostaje poza tym polem, jako zmysł pozbawiony sensu. Składają się na to wyróżnione wcześniej przyczyny, czyli dominująca hierarchia i racjonalny podział zmysłów w kulturze zachodniej, problem bliskości i sensualności badań humanistycznych, a także "nieuchwytność” definicyjna dotyku, jego "nieustanne przekraczanie granic każdego schematu interpretacji”28. W istocie obowiązujący model wiedzy akademickiej oparty jest na okulocentrycznej koncepcji wiedzy, zdystansowanej, abstrakcyjnej i sformalizowanej zarówno na poziomie nauczania, jak i uzyskiwania kolejnych stopni naukowych ${ }^{29}$.

Przyczyn nieistnienia antropologii taktylnej można upatrywać również w kolejnych zwrotach, jakie nastąpiły w naukach społecznych i humanistyce. W latach 6o. i 70. XX wieku wywołany zainteresowaniem pracami Ferdinanda de Saussure'a i Ludwiga Wittgensteina zwrot lingwistyczny sprawił, że kulturę zaczęto konceptualizować w kategoriach tekstu i języka. W latach 80. zwrot wizualny spowodował, że wielu akademików podjęło studia nad wizualnością i rolą, jaką odgrywa ona w przekazywaniu wartości kulturowych. Następnie, w latach 9o., pojęcia „wcielenia” oraz „materialności” stały się paradygmatami analizy kulturowej. Zwroty te, lub mówiąc inaczej negocjacje badań humanistycznych, jak twierdzi David Howes, wyczerpały się i dały początek studiom nad zmysłami, które do tej pory były zarezerwowane dla psychologów i neurobiologów skupionych na kognitywnych i neurologicznych aspektach percepcji.

Wzrost zainteresowania badaniami sensorycznymi na przełomie XXI wieku czerpie z każdego z tych wcześniejszych osiągnięć lub „zwrotów”,

26 Tamże, s. 99-100.

27 Zupełnie inną interpretację tego fragmentu proponuje Mattia Riccardi w tekście Nietzsche's sensualism, "European Journal of Philosophy” 2013 vol. 21, s. 219-257.

Sekwencja zmysłów dotyk - smak - węch - słuch - wzrok czytana od lewej do prawej wskazuje na zwiększenie dystansu, abstrakcji i formalizacji. Za: A. Synnott The Body Social, Routledge, London-New York 1993, s. 152. 
a także poddaje je krytyce, kwestionując logocentryczny model językowy, okulocentryczność modelu kultury wizualnej i holizm zarówno cielesnego, jak i materialnego modelu kultury - w których ciała i przedmioty są często traktowane po prostu jako całości fizyczne, a nie jako wiązki doświadczeń i właściwości. Studia nad zmysłami podkreślają dynamiczną, relacyjną (intersensoryczną - lub multimodalną, multimedialną) i nierzadko skonfliktowaną naturę naszych codziennych spotkań ze zmysłowym światem. ${ }^{30}$

Rewolucja zmysłowa, jak czasem określa się ten zwrot w badaniach ${ }^{31}$, przyniosła liczne publikacje, które można zaliczyć do badań z zakresu antropologii taktylnej, a dotyczących tak różnorodnych dziedzin wiedzy jak architektura i literaturoznawstwo, studia nad afektami i psychoanaliza, filozofia i filmoznawstwo ${ }^{32}$. Co więcej, studia skórne - skin studies - powołane przez Marca Lafrance'a, zwróciły uwagę na powierzchnię ciała jako tę, która jest przystosowana do życia, zrozumiała i znacząca, czyniąc podobne założenia jak studia nad cielesnością, uznające, że ciało jest „otwarte, procesualne, relacyjne i świadome; ludzkie i nieludzkie, materialne i niematerialne, nieokreślone i wielorakie; a co najważniejsze, związane z myśleniem i ponownym realnym przemyśleniem działania, władzy i technologii" ${ }^{\prime 3}$. To właśnie antropologia zmysłów, wraz ze studiami skórnymi, które stanowią najważniejszy punkt odniesienia dla antropologii taktylnej, uznały sensualność za sensowną, w znaczeniu sposobu pojmowania zarówno zjawisk fizycznych, jak i kanałów, przez które przekazywane są znaczenia kulturowe ${ }^{34}$.

\section{Zob. D. Howes Charting the Sensorial Revolution, "Senses \& Society” 2006, vol. 1, s. 113-128. \\ Zob. D. Howes The Expanding Field of Sensory Studies, https://www.sensorystudies.org/senso- rial-investigations/the-expanding-field-of-sensory-studies/ (10.04.2020).
Por. J. Pallasmaa Oczy skóry. Architektura i zmysły, przeł. M. Choptiany, Instytut Architektury, Kraków 2012; M. Paterson The senses of touch: Haptics, affects, and technologies, Berg, Oxford- New York 2007; N. Segal Consensuality: Didier Anzieu, gender and the sense of touch, Rodopi, Amsterdam 2009; J. Derrida On touching - Jean-Luc Nancy, transl. by C. Irizarry, Stanford Uni- versity Press, Stanford 2005; L.U. Marks Touch: sensuous theory and multisensory media, Univer- sity Of Minnesota Press, Minneapolis 2002.

M. Lafrance Skin studies: past, present and future, „Body \& Society” 2008 no. 24 (1/2), S. 3-32.
Nie poruszam tutaj kwestii różnic między kanadyjską i amerykańską antropologią zmysłową oraz antropologią sensoryczną - zob. K. Wala, K. Pietrowiak Antropologia zmysłów i sensoryczna etnografia - geneza, założenia, podejścia badawcze, „Etnografia. Praktyki, Teorie, Doświadcze- nia" $2018 \mathrm{nr}$ 4, s. $15-40$. 


\section{Kwestia bliskości?}

Jak trafnie stwierdziła Erin Manning, polityka dotyku nie jest polityką dotyku jako dotyku, lecz wcielonego doświadczenia kontaktu, ruchu ciała, który zasadza się na zakazie dotykania. „Takt ucieleśnia ten nakaz, według którego zawczasu p o w in na m w i ed zi éc, jak i kiedy mogę lub nie mogę dotykać"35. Słowo „takt” w języku polskim odnosi do umiejętności zachowania się w sposób opanowany, delikatny, niewywołujący konfliktów, jest ściśle związane z kontaktem i taktylnością. Warto zwrócić uwagę, że przedrostek "kon-" odwołuje do łacińskiego cum i contra, czyli odpowiednio "z" oraz „przeciwko", a samo contactus oznacza ni mniej, ni więcej dotykanie czegoś nieczystego, zarażenie (contagio), infekcję $e^{36}$. Kontakt można zatem rozumieć na trzy sposoby: jako „bycie z”, „bycie przeciwko taktowi” oraz „bycie w zagrożeniu”. Takie rozumienie kontaktu jest głęboko paradoksalne - z jednej strony pokazuje, że dotyk jest w najwyższym znaczeniu zmysłem relacyjnym, z drugiej że jest zawczasu podporządkowany konkretnym regułom zachowania jako zmysł niebezpieczny (pod względem biologicznym i społecznym). Można rzec, że wpisanie ograniczenia w zmysł dotyku taktu w taktylność - ma za zadanie, już na poziomie językowym, nadać temu zmysłowi jakiekolwiek ramy.

To na przełomie XVII i XVIII wieku łacińskie tact zostało zaczerpnięte przez język francuski i angielski na oznaczenie poczucia rozeznania w postępowaniu, dyplomacji czy intuicji dotyczącej poprawnego zachowania (po prawdzie takt rozumiany jako metrum muzyczne wyznacza sposób, w jaki ciało, które gra na instrumencie, poddane jest konkretnym ograniczenio$\mathrm{m})^{37}$. Można przypuszczać, że to właśnie wtedy zmysł dotyku (bliskości) stał się zmysłem społeczno-estetycznym (oddalenia). Ten paradoks kontaktu najlepiej oddaje występujące w języku angielskim wyrażenie be in touch with, które nie odwołuje bynajmniej do stanu „bycia w kontakcie dotykowym” lub „bycia w dotyku z", lecz do pozostawania w paradoksalnym stanie bycia blisko i zarazem daleko, do utrzymywania kontaktu - w sensie przekazywania

35 E. Manning Sensing beyond security: what a body can do, w: tejże, Politics of touch: sense, movement, sovereignty, University of Minnesota Press, Minneapolis 2007, s. 134. z pierwszych użyć literackich tego słowa: „istnieje takt moralny, który rozciąga się na wszystko, a którego niegodziwi nie posiadają". Zob. D. Diderot Entretiens sur le fils naturel, w: tegoż, Fuvres esthétiques, éd. P. Vernière, Garnier, Paris 2001, s. 126. 
sobie informacji - mimo dystansu przestrzennego i czasowego. Anne Carson w eseju Dirt and desire zapisała:

Prawdopodobnie najtrudniejszą kwestią, wobec której jako członkowie ludzkich społeczeństw na co dzień stajemy, jest wzajemny dotyk - bez względu na to, czy jest on fizyczny, moralny, emocjonalny, czy też wyobrażeniowy. Kontakt to kryzys. [...] Trudność ujawniająca się w sytuacji kontaktu dotyczy naruszenia ustalonej granicy, przekroczenia ściśle wytyczonej kategorii, do której on się nie wpisuje. ${ }^{38}$

Kryzys ten dotyczy uzmysłowienia, czyli, po pierwsze, pojawienia się w opisywanym wcześniej przez Nietzschego - kręgu zmysłowym tego, czemu zmysły, podobnie jak umysły, nie były dotąd zdolne nadać sensu ${ }^{39}$. Po drugie, ze staniem się „zmysłowym”, a więc wrażliwym na coś, co dotychczas mimo przestrzennej bliskości umykało uwadze. Po trzecie, z wyobcowaniem z siebie, które Tadeusz Sławek opisuje następująco:

Dotyk spełnia swoją podstawową funkcję właśnie z racji [...] radykalnie indywidualnego charakteru: dotykając [...] osobowo (a nie tylko "osobiście"), obcuję z tym, co nie jest tylko po prostu „dotykane", lecz co odwzajemnia mój dotyk. Dlatego czasownik „obcować” nabiera tu specjalnego znaczenia. Mówi nie tylko o przebywaniu w bliskości kogoś, lecz także o stawaniu się „obcym” dla samego siebie, o wy-obcowywaniu się z pewności siebie, której nabywamy, posługując się utartymi schematami poznawania i rozumienia świata. ${ }^{40}$

W istocie oddalenie zmysłu bliskości ma na celu zażegnanie kryzysu, jaki dotyk ze sobą przynosi. Kryzysu w znaczeniu utraty oddalonej, bezpiecznej pozycji. Względem własnego ciała, którego bezpośrednie doświadczenie, jak

38 A. Carson Dirt and desire: essay on the phenomenology of female pollution in antiquity, w: tejże, Men in the off hours, Vintage, New York 2001, s. 130.

39 Rozróżnienia dotyczące "uzmysłowienia" przejmuję od Georges'a Didi-Hubermana, który sformułował je w zupełnie innym kontekście, dotyczącym historii i obrazowania ludu. Por. G. Didi-Huberman Uzmysłowienie, przeł. P. Mościcki, „Widok. Teorie i Praktyki Kultury Wizualnej” $2014 \mathrm{nr}$ 6, http://www.pismowidok.org/pl/archiwum/2014/6-obraz-patos/uzmyslowienie (10.04.2020).

40 T. Sławek Cienie i rzeczy. Rozważania o dotyku, w: W przestrzeni dotyku, red. J. Kurek, K. Maliszewski, Miejski Dom Kultury „Batory”, Chorzów 2009, s. 22. 
słusznie zauważa François Chirpaz, polega na tym, że nie poddaje się ono w przeciwieństwie do rzeczy należących do świata - badaniu, manipulacji czy obserwacji ${ }^{41}$, a także wobec innych ciał ludzkich i nieludzkich. Wejście w kontakt jest momentem zrównania, w którym każdy, kto dotyka i jest dotykanym, ma tę samą zdolność odczuwania.

Warto przywołać tutaj używane w Japonii pojęcie skinship, które określa zarówno wszelkie zachowania taktylne między matką i dzieckiem (wspólne kąpiele, spanie, karmienie piersią czy onbu, czyli noszenie dziecka na plecach) ${ }^{42}$, jak i nieerotyczny dotyk między osobami dorosłymi (mający swoje źródło w izolacji współczesnego japońskiego społeczeństwa oraz obostrzeniach kulturowych) ${ }^{43}$. Pojęcie to pochodzi z zestawienia słów skin (skóra) oraz kinship (pokrewieństwo, pobratymstwo) i pozwala się zastosować w znacznie szerszym rozumieniu. Skinship czy, jak proponuje Aleksandra Reszelska ${ }^{44}$, ciałokrewieństwo może określać relację podobieństwa, jaka zachodzi między czującymi ciałami/skórami bez względu na przynależność gatunkową. Pokrewność nie dotyczy ani rodziny, ani nawet istot ludzkich, nie wiąże się również z identycznością czy jednakowością, lecz wskazuje na istnienie zbiorowości ludzko-nieludzkiej dzielącej ze sobą zdolność odczuwania. Ta pokrewność łączy się z nadaniem prawa do odczuwania każdemu żywemu organizmowi w sposób wyrażony przez Jolantę Brach-Czainę: „ludzka skóra stanowi obwiednię wszystkiego, co znajduje się poza nią. Jest więc powłoką świata"45.

Indywidualny charakter doświadczenia taktylnego zasadza się natomiast na zgodności. Mówiąc inaczej: nie chcę być dotykany niezgodnie z moimi potrzebami i pragnieniami - i odwrotnie, nie chcę dotykać w niezgodzie z czyimiś potrzebami i pragnieniami ${ }^{46}$.Zmysł dotyku w najwyższym stopniu

41 F. Chirpaz Ciało, przeł. J. Migasiński, Wydawnictwo IFiS PAN, Warszawa 1998, s. 11-12.

42 Zob. D.A. Tahhan Parent-child touch: (dis)locating the body in skinship, w: tejże, The Japanese family: touch, intimacy and feeling, Routledge, London-New York 2014, s. 25-59.

43 W serialu dokumentalnym przygotowanym przez Christiane Amanpour Sex \& love around the world (2018), w odcinku poświęconym Japonii, słowem tym posługuje się jeden z mężczyzn do wynajęcia na określenie kontaktu, jaki utrzymuje ze swoimi klientkami.

44 A. Reszelska Skóra do skóry czyli ciałokrewieństwo, „Przekrój” 2019 nr 3566, https://przekroj.pl/ spoleczenstwo/skora-do-skory-czyli-cialokrewienstwo-aleksandra-reszelska (10.04.2020).

45 J. Brach-Czaina Dotknięcie świata, s. 62.

46 Por. R. Kearney The wager of Carnal hermeneutics, w: Carnal hermeneutics, ed. by R. Kerney, B. Treanor, Fordham University Press, New York 2015, s. 16. 
dotyczy granic, zarówno w odniesieniu do ciała (np. w kontekście kategorii dobrego i złego dotyku) ${ }^{47}$, myślenia (dychotomii wnętrza/zewnętrza, ludzkiego/nieludzkiego, ciała/rozumu etc.), jak i polityki (szerzej - wzorca zmysłowego, za którym opowiada się konkretne społeczeństwo i dzięki któremu członkowie tego społeczeństwa uzmysławiają sobie świat lub przekładają wrażenia i koncepty zmysłowe na konkretny światopogląd) ${ }^{48}$. Doświadczenie taktylne wprawia w ruch wszystkie te granice i ustala je za każdym razem inaczej, względem konkretnej realności społeczno-kulturowej, dla mnie i dla innych. Nie sposób zatem mówić o "my" dotykającym. Laura Marks wyraziła to obrazowo w odniesieniu do zmysłu zapachu:

Powiedzmy, że przygotowujesz jako dziecko swoje pierwsze bożonarodzeniowe pierniczki i twoja mama dała ci klapsa za rozsypanie cynamonu. Po tym wydarzeniu będziesz miał silne i emocjonalnie negatywne wspomnienie cynamonu. Co więcej, będzie ono odmienne od większości e m o cj o n a l ny ch wspomnień tej przyprawy. Twoje skojarzenie z szarym mydłem prawdopodobnie różni się w dużym stopniu od mojego, które wiąże się z bezwzględną babcią (która w wieku 93 lat znacząco złagodniała, niech spoczywa w pokoju). Skojarzenia, jakie posiadamy w związku z zapachami, są silnie zindywidualizowane i uzależnione od kontekstu, i pozostaną takie dopóty, dopóki ludzie charakteryzować się będą odmiennymi doświadczeniami życiowymi. ${ }^{49}$

Oczywiście możliwe jest ujęcie ogólnych zjawisk taktylnych, odrębnych wzorów zmysłowych, zachowań charakterystycznych dla dużych grup społecznych czy stworzenie teorii pomocnych w rozumieniu i opisaniu doświadczenia taktylnego. Niemniej antropolodzy taktylni powinni przede wszystkim uwzględniać subiektywny, relacyjny, dynamiczny wymiar tego doświadczenia, porzucając odległe i obiektywne punkty widzenia na rzecz bliskich, oblekających całe ciało i podległych wpływom emocjonalnym punktom dotyku.

47 Zob. T. Field Touch, A Bradford Book, Cambridge-London 2001.

C. Classen Foundations for an anthropology of the senses, "International Social Science Journal” 1997 no. 49 (153), s. 401-412. 


\section{Odkrycie dotyku}

Nieistnienie antropologii taktylnej jest ściśle związane z pozycją, jaką zmysł dotyku zajmuje w kulturze zachodniej. To zmysł zapomniany, oczywisty, niewidzialny, zmysł niedefiniowalny lub pełniący funkcję definicyjnego worka, w którym można umieścić wszystko, co pozawzrokowe, subiektywne, afektywne czy ogólnie cielesne ${ }^{50}$, zmysł pod wieloma względami niebezpieczny, zarówno na poziomie biologicznym (powiązany z groźbą zakażenia), jak i społecznym (pragnienie pokonania dystansu stymulowane jest różnorodnymi trybami odległości) ${ }^{51}$, wreszcie podający w wątpliwość językowo-wizualny wzorzec myślenia (zwłaszcza akademickiego). Stworzenie tej dziedziny badań nie łączy się z odwróceniem hierarchii i kolejnym podziałem zmysłów, to jest uznaniem dotyku za zmysł najważniejszy, oddzieleniem go od pozostałych zmysłów etc. Przyczynienie się do istnienia tej dziedziny wiąże się przede wszystkim ze sproblematyzowaniem doświadczenia taktylnego, ukazania zmysłu dotyku jako intermodalnego, czyli splatającego wrażenia pochodzące z różnych zmysłów ${ }^{52}$, jako zmysłu, który domaga się pogłębionego opracowania teoretycznego (tak jak to jest w odniesieniu do zmysłu wzroku i słuchu), wreszcie jako zmysłu krytycznego wobec wielu konstruktów kulturowo-społecznych (np. zdystansowanego badacza). Dziedzina ta ma śledzić nie tylko modele kulturowe kształtujące ludzką percepcję, lecz także to, jak „doświadczenie widzenia, słyszenia, czucia karmi wyobraźnię i wtapia się w dyskurs oraz ekspresje literackie" ${ }^{53}$. Co więcej, wspierać te wszystkie działania i interakcje wykraczające poza ekspresję audiowizualną w poszukiwaniu innych form postrzegania i opisywania rzeczywistości. Ostatecznie antropologia taktylna jest dziedziną badań, której zadaniem jest odkrycie kultury dotykowej i jej rozwinięcie.

Zob. M. Niedźwiecki Dystans i dotyk: „kryzys widzenia”, „Sztuka i Filozofia” 1999 nr 16, s. 194-210; G. Świtek W ciemnościach. Historia sztuki i sztuka dotyku, "Roczniki Humanistyczne” 2010 z. 4, s. 269-289; A. Chromik Dotyk, rytm i współświadczenie. O afektywnym potencjale materialności itaktyIności w twórczości Brachy Ettinger , Widok. Teorie i Praktyki Kultury Wizualnej” 2019 nr 23, S. 1-31.

51 N. Segal Touching and not touching: the indirections of desire, w: Touch, ed. by C. Nirta, D. Mandic, A. Pavoni, A. Philippopoulos-Mihalopoulos, University of Westminster Press, London 2020, s. 30 .

Por. M. Paterson Seeing with the hands, touching with the eyes, w: tegoż The senses of touch, s. 37-57.

Za: K. Wala, K. Pietrowiak Antropologia zmysłów i sensoryczna etnografia, s. 33. 


\section{Abstract}

\section{Maciej Topolski}

JAGIELLONIAN UNIVERSITY (CRACOW)

Tactile Anthropology: An Introduction

Topolski proposes to set up the research field of tactile anthropology to explore the broadly understood sense of touch. First he outlines the biological functions of touch, the meanings attributed to it in Western culture, and the definitional complexity of this sense. In the following sections, he describes the goals and guidelines of tactile anthropology, locating this research field in anthropology of the senses. Then he discusses the following issues: closeness in the socio-cultural and academic context, the politics of the sense of touch combined with the concept of tact and skinship, which allows to think about non-human dimension of skin.

\section{Keywords}

touch, sensory, tactile, tactile anthropology, anthropology of the senses 